\title{
Leukocyte adhesion deficiency type II
}

INSERM

\section{Source}

INSERM. (1999). Orphanet: an online rare disease and orphan drug data base. Leukocyte adhesion deficiency type II. ORPHA:99843

Leukocyte adhesion deficiency type II (LAD-II) is a form of LAD (see this term) characterized by recurrent bacterial infections, severe growth delay and severe intellectual deficit. 